\title{
Accumulation of alkaloids in plants of the family Boraginaceae depending on environmental conditions places of growth
}

\author{
Amina A. Akhkubekova*, and Aida Ya. Tamakhina \\ Kabardino-Balkarian State Agrarian University named after V.M. Kokova, Lenin Ave., 1v,360030 \\ Nalchik, Russia
}

\begin{abstract}
Due to the lack of information on the influence of environmental factors on the accumulation of pyrrolizidine alkaloids and their content in certain species of this family Boraginaceae, the aim of the study was to assess the level of alkaloids accumulation in the aboveground and underground parts of Symphytum asperum Lepech., S. caucasicum M. Bieb., Echium vulgare L., and Pulmonaria mollis Wulfen ex Hornem. depending on climatic, orographic and edaphic conditions. The localization of alkaloids in rhizomes with roots, glandular trichomes of leaves and stems, epidermal cells was revealed. The content of alkaloids in the aboveground phytomass decreases in the series $S$. asperum $>S$. caucasicum $>$ E. vulgare, and in the underground $S$. caucasicum $>S$. asperum $>E$. vulgare $>$ $P$. mollis. At the end of the growing season, an increase in the accumulation of alkaloids in the underground phytomass and a decrease in the aboveground one were noted. An increase in air temperature and a decrease in precipitation contribute to an increase in the accumulation of alkaloids in roots and shoots. The level of correlation between the accumulation of alkaloids and the content of trace elements varies from high $(\mathrm{Cu}$, $\mathrm{Zn}, \mathrm{Mo})$ to medium $(\mathrm{Mn}, \mathrm{Pb})$. The results obtained indicate the need to take into account environmental factors in the implementation of medicinal collections and the preparation of feed from plants.
\end{abstract}

\section{Introduction}

To date, more than 1,500 alkaloids have been identified, which synthesize about $20 \%$ of vascular plants [1]. Alkaloids are involved in the neutralization of ammonia and nitrogen reserve, they function as growth regulators, phytoncides, photosensitizers, exhibit allelopathic properties, participate in maintaining the ionic balance of cells, and protect plants from stress factors $[2,3]$. The accumulation of alkaloids depends on various factors (intensity of sunlight, water deficit, high air temperature at low relative humidity, an increase in nitrogen and calcium in the soil, salinity, soil pollution with heavy metals) [4-6]. The highest alkaloid content in the aboveground part of herbaceous plants is observed in the flowering phase, and in rhizomes it increases during the wilting phase of the aboveground parts [2]. Under conditions of a sharp deficiency or excess of mineral nutrients, the accumulation of

${ }^{*}$ Corresponding author: aida17032007@yandex.ru 
alkaloids decreases, which underlies the universal M-shaped dependence of the formation and accumulation of alkaloids in plants on their supply of mineral nutrients [7].

In terms of chemical structure, alkaloids of species of the Boraginaceae family belong to the pyrrolizidine group. The toxicity of pyrrolizidine alkaloids is based on their ability to alkylate DNA, cause mutations and oncological diseases [8]. The most toxic pyrrolizidine alkaloids are lasiocarpine, echimidine, and symphitine $[9,10]$. The content of pyrrolizidine alkaloids in plants of the family. Boraginaceae varies from $0.04 \%$ to $0.6 \%$ [11].

The widespread distribution of Borage family in Russia, including in the North Caucasus, and the use of certain species in fodder production and folk medicine, especially with uncontrolled collection of medicinal raw materials, dictates the need to control the content of alkaloids in various parts of plants. Due to the lack of information on the influence of environmental factors on the accumulation of pyrrolizidine alkaloids and their content in certain species of this family. Boraginaceae, the aim of the study was to assess the level of accumulation of alkaloids in the aboveground and underground parts of Symphytum asperum Lepech., S. caucasicum M. Bieb., Echium vulgare L., Pulmonaria mollis Wulfen ex Hornem. depending on climatic (temperature, precipitation), orographic (altitude) and edaphic (content of mobile forms of microelements in the soil) factors.

\section{Materials and methods}

The studies were carried out on the territory of the Kabardino-Balkarian Republic in 20172019. The objects of the study were plants of rough comfrey (Symphytum asperum Lepech.) and caucasian (Symphytum caucasicum M. Bieb.), Common bruise (Echium vulgare L.) and soft lungwort (Pulmonaria mollis Wulfen ex Hornem.). Plant samples (10-12 pcs. from each location) were collected in the phases of flowering and seed formation 3-fold repetition. The collected material was fractionated into rhizomes with roots and stems with leaves. The material was washed, dried at a temperature of $40-50{ }^{\circ} \mathrm{C}$, and ground to a particle size of 2-3 mm. To establish the localization of alkaloids, pre-discolored leaves and stems were treated with Dragendorff's reagent. The determination of the quantitative content of alkaloids was carried out by a gravimetric method based on the quantitative precipitation of alkaloids with a solution of silicotungstic acid with the formation of complex salts. Analytical replication three times. The selection of soil samples in the place of growth of the species was carried out from the upper layer $(0-20 \mathrm{~cm})$. The content of heavy metals in soil (mobile forms of metals) and plant samples was determined by the atomic absorption method with electrothermal atomization. Statistical processing included the determination of the correlation coefficients $(\mathrm{r})$ and variation $(\mathrm{CV} \%)$.

\section{Results and Discussion}

Plant growing areas vary in climatic and orographic conditions (Table 1).

Table 1. Climatic (average monthly temperature and the amount of precipitation for March-August, average for 2017-2019) and orographic conditions of plant growth sites

\begin{tabular}{|c|c|c|c|c|c|}
\hline Species & $\begin{array}{c}\mathrm{N} \\
\text { location }\end{array}$ & Place of growth & $\begin{array}{c}\text { Temperature, } \\
{ }^{\circ} \mathrm{C}\end{array}$ & $\begin{array}{c}\text { Amount of } \\
\text { precipitation, } \\
\mathrm{mm}\end{array}$ & $\begin{array}{c}\text { Height, } \\
\text { m above sea level }\end{array}$ \\
\hline $\begin{array}{c}\text { P. } \\
\text { mollis }\end{array}$ & 1 & $\begin{array}{c}\text { A ravine in an oak-pine } \\
\text { forest on Mount Bolshaya } \\
\text { Kizilovka }\end{array}$ & 16,96 & 408,8 & 847 \\
\cline { 2 - 6 } & 2 & $\begin{array}{c}\text { The Natural Boundary } \\
\text { Dzhily-Su }\end{array}$ & 10,25 & 346,7 & 2380 \\
\hline
\end{tabular}




\begin{tabular}{|c|c|c|c|c|c|}
\hline & 3 & $\begin{array}{l}\text { Floodplain forest of the } \\
\text { Urvan river, vil. Chernaya } \\
\text { Rechka }\end{array}$ & 16,62 & 402,6 & 264 \\
\hline & 4 & $\begin{array}{l}\text { Felling areas of oak-pine } \\
\text { forest along the road in the } \\
\text { vicinity of Nalchik }\end{array}$ & 16,96 & 408,8 & 830 \\
\hline \multirow{4}{*}{$\begin{array}{l}\text { cauca- } \\
\text { sicum }\end{array}$} & 5 & vil. Etoko & 16,82 & 380,5 & 570 \\
\hline & 6 & vil. Alexandrovskaya & 18,28 & 350,6 & 255 \\
\hline & 7 & $\begin{array}{l}\text { vil. Kashhatau in the valley } \\
\text { of the river Cherek }\end{array}$ & 19,43 & 315,2 & 848 \\
\hline & 8 & $\begin{array}{l}\text { c vil. Lechinkai rural set- } \\
\text { tlement, Chegem riverbank }\end{array}$ & 19,16 & 327,2 & 680 \\
\hline \multirow{4}{*}{$\begin{array}{l}\text { asper- } \\
\text { um }\end{array}$} & 9 & $\begin{array}{l}\text { Abandoned garbage dump } \\
\text { on the outskirts of Nalchik }\end{array}$ & 18,31 & 320,2 & 514 \\
\hline & 10 & $\begin{array}{l}\text { vil. Genal (valley of the } \\
\text { river Zolka) }\end{array}$ & 16,37 & 408,8 & 880 \\
\hline & 11 & $\begin{array}{l}\text { Surroundings of vil. Tash- } \\
\text { ly-Tala }\end{array}$ & 11,30 & 364,1 & 1120 \\
\hline & 12 & $\begin{array}{l}\text { vil. Aleksandrovskaya, } \\
\text { construction waste dump }\end{array}$ & 18,12 & 332,3 & 260 \\
\hline \multirow[t]{4}{*}{$\begin{array}{l}\text { E. } \\
\text { vulgare }\end{array}$} & 13 & $\begin{array}{l}\text { vil. Altud, old steppe } \\
\text { deposit }\end{array}$ & 17,52 & 390,8 & 226 \\
\hline & 14 & $\begin{array}{l}\text { The lower terrace of the } \\
\text { tailings of the Tyrnyauz } \\
\text { tungsten-molybdenum } \\
\text { plant }\end{array}$ & 18,38 & 328,4 & 1128 \\
\hline & 15 & $\begin{array}{l}\text { vil. Aushigere, a site con- } \\
\text { taminated with construc- } \\
\text { tion waste }\end{array}$ & 14,43 & 397,1 & 620 \\
\hline & 16 & vil. Malka, steppe meadow & 18,02 & 360,4 & 648 \\
\hline
\end{tabular}

In the considered ecotypes, the influence of climatic and orographic factors is significantly different. The range of temperatures in the areas of growth of $P$. mollis, S. caucasicum, S. asperum and E. vulgare amounted to 3.37 , respectively; $2.78 ; 7.01$ and $3.95{ }^{\circ} \mathrm{C}$, precipitation - 88.7; 65.3; 88.6; $68.7 \mathrm{~mm}$; heights - 2116; 593; 860 and $902 \mathrm{~m}$ above sea level. The content of mobile forms of metals in the soil of the studied areas is presented in Table 2.

Table 2. Average content of mobile forms of metals in the soil of the studied areas, $\mathrm{mg} / \mathrm{kg}$

\begin{tabular}{|l|c|c|c|c|c|}
\hline N location & $\mathrm{Cu}$ & $\mathrm{Mn}$ & $\mathrm{Zn}$ & $\mathrm{Pb}$ & $\mathrm{Mo}$ \\
\hline 1 & 0,26 & 21,28 & 8,26 & 2,12 & 0,09 \\
\hline 2 & 0,28 & 20,35 & 5,52 & 2,54 & 0,11 \\
\hline 3 & 0,22 & 14,15 & 9,45 & 2,18 & 0,12 \\
\hline 4 & 0,56 & 33,12 & 14,86 & 4,28 & 0,18 \\
\hline 5 & 0,34 & 22,86 & 7,46 & 2,73 & 0,08 \\
\hline 6 & 0,93 & 36,32 & 15,52 & 5,54 & 0,16 \\
\hline 7 & 0,82 & 37,88 & 18,11 & 5,16 & 0,20 \\
\hline 8 & 0,48 & 14,32 & 14,48 & 2,32 & 0,11 \\
\hline 9 & 1,26 & 32,14 & 10,34 & 3,62 & 0,19 \\
\hline 10 & 0,29 & 20,50 & 8,12 & 2,63 & 0,16 \\
\hline 11 & 0,19 & 14,12 & 5,35 & 1,20 & 0,20 \\
\hline 12 & 1,46 & 53,26 & 8,60 & 5,53 & 0,18 \\
\hline 13 & 0,84 & 56,47 & 6,5 & 5,65 & 0,12 \\
\hline 14 & 2,48 & 79,34 & 12,52 & 27,67 & 2,76 \\
\hline 15 & 0,64 & 38,34 & 5,26 & 5,26 & 0,19 \\
\hline 16 & 0,72 & 22,90 & 7,25 & 2,37 & 0,17 \\
\hline MAC, mg/kg & 3,0 & 80,0 & 23,0 & 6,0 & 0,20 \\
\hline
\end{tabular}

The soils of the habitats of $P$. mollis and $S$. caucasicum are characterized by moderate 
variability of mobile forms of metals, S. asperum - from weak to noticeable, E. vulgare from moderate to very high. At site 14 , the content of $\mathrm{Pb}$ and Mo exceeds the general sanitary standard $(6.0 \mathrm{mg} / \mathrm{kg})$ and the background content $(0.2 \mathrm{mg} / \mathrm{kg})$ by 4.6 and 13.8 times, respectively. In the phytomass of $P$. mollis, $S$. caucasicum, and $S$. asperum, the variability in the content of $\mathrm{Cu}, \mathrm{Mn}$, and $\mathrm{Zn}$ is weak, which indicates the homeostasis of biogenic microelements. The content of $\mathrm{Mo}$ and $\mathrm{Pb}$ in plants is characterized by moderate and noticeable variability (Fig. 1).

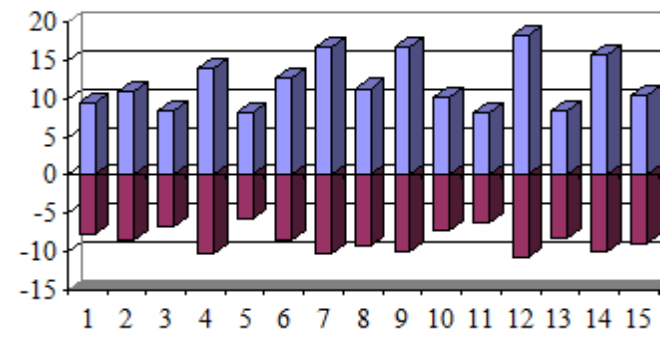

a)

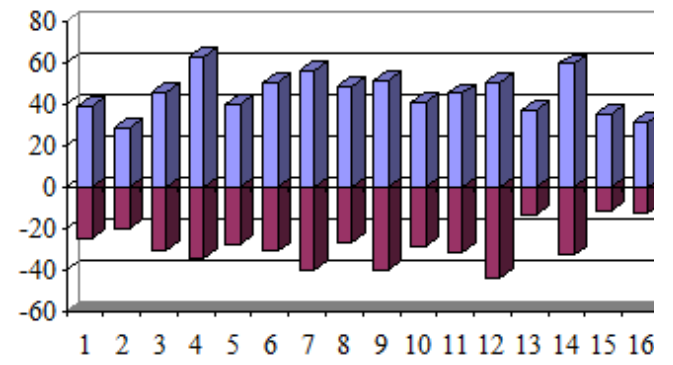

c)

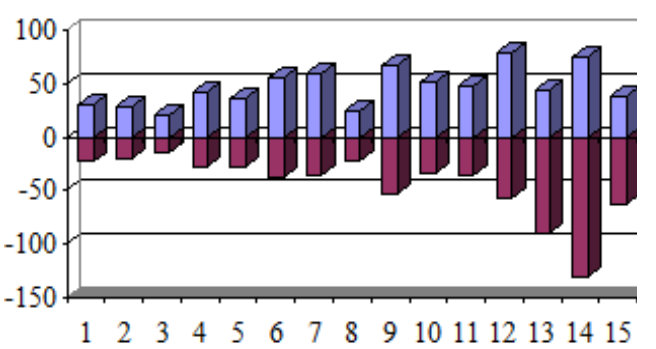

b)

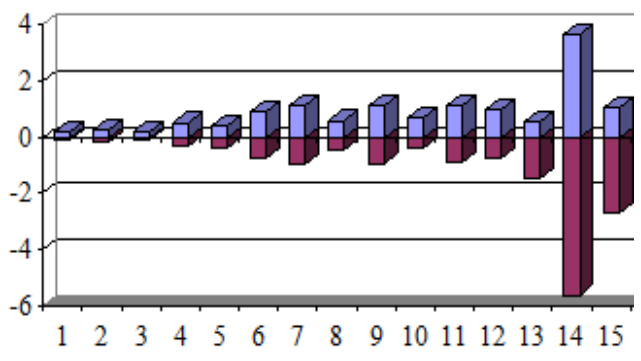

d)

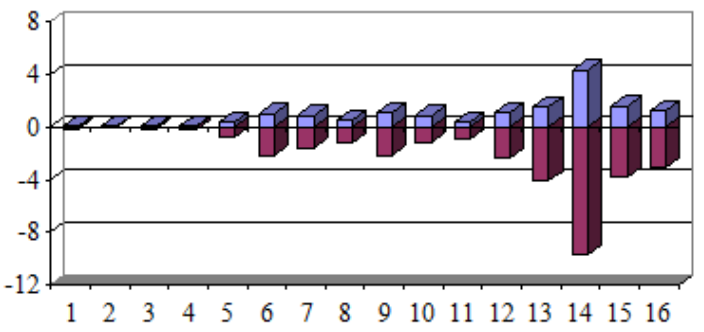

e)

aboveground phytomass

underground phytomass

Fig. 1. Content of $\mathrm{Cu}(\mathrm{a}), \mathrm{Mn}(\mathrm{b}), \mathrm{Zn}(\mathrm{c}), \mathrm{Mo}(\mathrm{d}), \mathrm{Pb}(\mathrm{e})$ in aboveground and underground phytomass, $\mathrm{mg} / \mathrm{kg}$.

Alkaloids of the studied species are present in rhizomes with roots (positive reaction with the Dragendorff reagent). In the leaves and stems of $S$. asperum, $S$. caucasicum, and $E$. vulgare alkaloids are localized in glandular trichomes, as well as in epidermal cells adjacent to the base of individual covering hairs (Fig. 2). The presence of alkaloids in glandular trichomes of certain plant species is confirmed by a number of authors [12, 13]. Nonspecialized covering hairs with alkaloids have high metabolic activity [14]. 

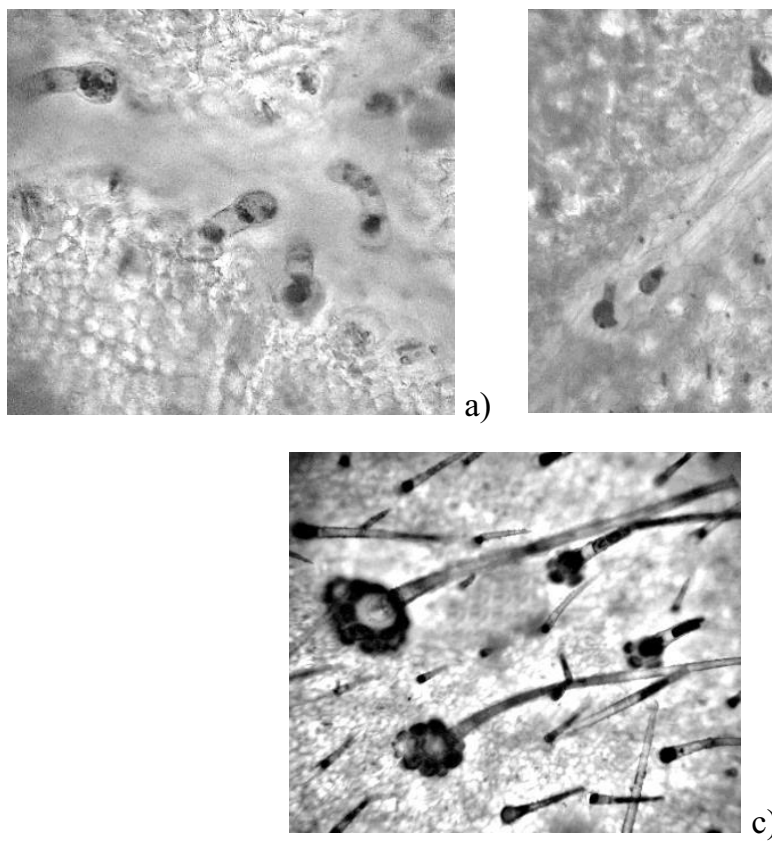

b)

Fig. 2. Localization of alkaloids in leaf trichomes S. asperum (a), S. caucasicum (b), E. vulgare (c).

Plants of the studied species are characterized by a relatively low content of alkaloids $(<1 \%)$. The level of alkaloids accumulation in the aboveground phytomass decreases in the series $S$. asperum $>S$. caucasicum $>$ E. vulgare, and in the underground - S. caucasicum $>$ S. asperum $>$ E. vulgare $>P$. mollis (Table 3).

Table 3. The alkaloid content (\% by weight abs. dry. raw materials) depending on the vegetation phase of plants

\begin{tabular}{|c|c|c|c|c|c|}
\hline \multirow[t]{2}{*}{ Species } & \multirow{2}{*}{$\begin{array}{c}\mathrm{N} \\
\text { location }\end{array}$} & \multicolumn{2}{|c|}{ Flowering } & \multicolumn{2}{|c|}{ Seed formation } \\
\hline & & $\begin{array}{c}\text { aboveground } \\
\text { phytomass }\end{array}$ & $\begin{array}{l}\text { underground } \\
\text { phytomass }\end{array}$ & $\begin{array}{l}\text { aboveground } \\
\text { phytomass }\end{array}$ & $\begin{array}{l}\text { underground phyto- } \\
\text { mass }\end{array}$ \\
\hline \multirow[t]{4}{*}{ P. mollis } & 1 & - & 0,048 & - & 0,062 \\
\hline & 2 & - & 0,052 & - & 0,081 \\
\hline & 3 & - & 0,035 & - & 0,056 \\
\hline & 4 & - & 0,068 & - & 0,094 \\
\hline \multicolumn{2}{|c|}{$\bar{X} \pm m$} & & $0,051 \pm 0,007$ & & $0,073 \pm 0,009$ \\
\hline \multicolumn{2}{|c|}{$\mathrm{CV}, \%$} & - & 26,79 & - & 23,84 \\
\hline \multirow{4}{*}{$\begin{array}{l}S . \quad \text { cau- } \\
\text { casicum }\end{array}$} & 5 & 0,086 & 0,239 & 0,073 & 0,340 \\
\hline & 6 & 0,130 & 0,325 & 0,125 & 0,394 \\
\hline & 7 & 0,307 & 0,446 & 0,279 & 0,508 \\
\hline & 8 & 0,202 & 0,358 & 0,196 & 0,416 \\
\hline \multicolumn{2}{|c|}{$\bar{X} \pm m$} & $0,181 \pm 0,048$ & $0,342 \pm 0,043$ & $0,168 \pm 0,045$ & $0,414 \pm 0,035$ \\
\hline \multicolumn{2}{|c|}{$\mathrm{CV}, \%$} & 53,25 & 25,02 & 53,14 & 16,90 \\
\hline \multirow{4}{*}{$\begin{array}{l}\text { S. asper- } \\
\text { um }\end{array}$} & 9 & 0,148 & 0,268 & 0,127 & 0,384 \\
\hline & 10 & 0,078 & 0,314 & 0,062 & 0,405 \\
\hline & 11 & 0,113 & 0,201 & 0,096 & 0,238 \\
\hline & 12 & 0,190 & 0,262 & 0,183 & 0,320 \\
\hline \multicolumn{2}{|c|}{$\bar{X} \pm m$} & $0,132 \pm 0,024$ & $0,261 \pm 0,023$ & $0,117 \pm 0,026$ & $0,337 \pm 0,038$ \\
\hline \multicolumn{2}{|c|}{$\mathrm{CV}, \%$} & 36,61 & 17,76 & 43,92 & 22,30 \\
\hline \multirow{2}{*}{$\begin{array}{l}\text { E. } \\
\text { vulgare }\end{array}$} & 13 & 0,076 & 0,065 & 0,070 & 0,092 \\
\hline & 14 & 0,156 & 0,102 & 0,132 & 0,113 \\
\hline
\end{tabular}




\begin{tabular}{|c|c|c|c|c|c|}
\hline & 15 & 0,082 & 0,070 & 0,074 & 0,082 \\
\cline { 2 - 5 } & 16 & 0,109 & 0,062 & 0,096 & 0,073 \\
\hline $\bar{X} \pm m$ & $0,106 \pm 0,018$ & $0,075 \pm 0,009$ & $0,095 \pm 0,016$ & $0,090 \pm 0,008$ \\
\hline $\mathrm{CV}, \%$ & 34,13 & 24,94 & 34,60 & 19,09 \\
\hline
\end{tabular}

The content of alkaloids in the underground phytomass of $S$. caucasicum and S. asper$u m$ exceeds the analogous indicator in the aboveground part both in the flowering phase and in the Seed Formation Stage. At the end of the growing season, there is an increase in the total content of alkaloids in the roots (by 21.0-29.2\%) and a decrease in stems with leaves (by 7.2-12.8\%). In E. vulgare plants, the content of alkaloids is higher in the aboveground phytomass. In the Seed Formation Stage, the content of alkaloids in the stems with leaves decreases by $11.6 \%$, and in the roots increases by $20.0 \%$. In P. mollis plants, alkaloids accumulate mainly in rhizomes with roots. The content of alkaloids in the aboveground phytomass of $S$. asperum, E. vulgare is characterized by moderate, and $S$. caucasicum - noticeable variability. Moreover, in the underground phytomass of the studied species, the content of alkaloids varies slightly.

Between the accumulation of alkaloids in the shoots, the temperature and the amount of precipitation, respectively, average $(r=0.53 \ldots 0.55)$ and high negative $(r=-0.81 \ldots-0.83)$ relationships were revealed. The correlation relationship between the content of alkaloids in the underground phytomass and temperature is weak $(\mathrm{r}=0.39 \ldots 0.41)$, and precipitation is medium negative $(\mathrm{r}=-0.53 \ldots-0.55)$. In general, high air temperature and a decrease in precipitation contribute to an increase in the accumulation of alkaloids in roots and shoots, which confirms the role of alkaloids in the adaptation of plants to climatic stress factors. Air temperature and humidity have a greater effect on the content of alkaloids in aboveground plant organs than in underground [4].

Height above sea level correlates very weakly with the content of alkaloids in shoots and roots $(\mathrm{r}=0.16)$. This is due to the location of the majority of the surveyed areas below the area with the predominant content of short-wave radiation in sunlight [15]. The strength of the relationship between the accumulation of alkaloids in the underground phytomass of the studied species and the content of mobile forms of metals in the soil decreases in the order $\mathrm{Cu}>\mathrm{Zn}>\mathrm{Mn}>\mathrm{Mo}>\mathrm{Pb}$, and in the aboveground $-\mathrm{Cu}>\mathrm{Zn}>\mathrm{Mo}=\mathrm{Pb}>\mathrm{Mn}$ (Fig. 3). The accumulation of alkaloids in the roots correlates with the content of metals in the underground phytomass $(\mathrm{Cu}>\mathrm{Mo}>\mathrm{Mn}>\mathrm{Zn}>\mathrm{Pb})$, and in the shoots - with the content of metals in the aboveground phytomass $(\mathrm{Cu}>\mathrm{Zn}>\mathrm{Mo}>\mathrm{Mn}>\mathrm{Pb})$. The level of correlation between the accumulation of alkaloids and the content of trace elements in plants varies from high $(\mathrm{Cu}$, $\mathrm{Zn}, \mathrm{Mo})$ to medium $(\mathrm{Mn}, \mathrm{Pb})$.

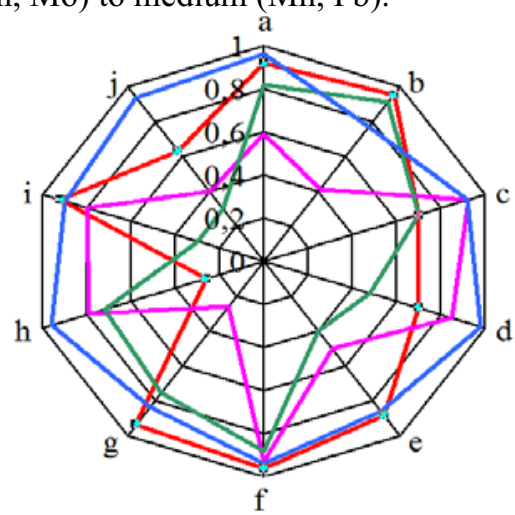

f

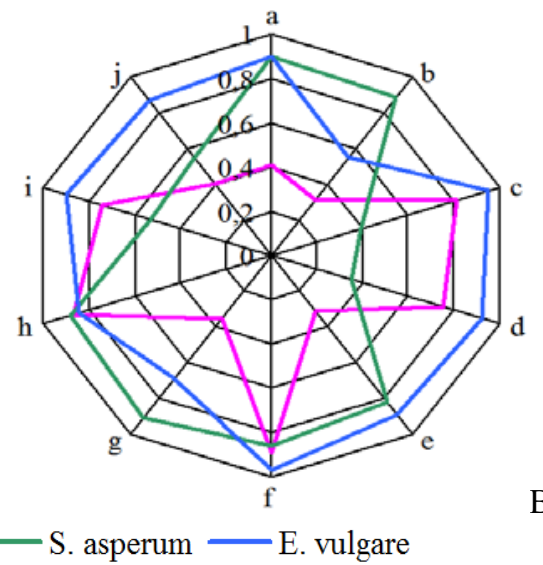

Fig. 3. Correlation between the content of mobile forms $\mathrm{Cu}$ (a), $\mathrm{Mn}(\mathrm{b}), \mathrm{Zn}$ (c), $\mathrm{Mo}$ (d), $\mathrm{Pb}$ (e) in soil, $\mathrm{Cu}(\mathrm{f}), \mathrm{Mn}(\mathrm{g}), \mathrm{Zn}(\mathrm{h}), \mathrm{Mo}(\mathrm{i}), \mathrm{Pb}(\mathrm{j})$ in the underground (A) and aboveground (B) phytomass. 
Plants of E. vulgare, growing in conditions of extremely high pollution with $\mathrm{Pb}$ and $\mathrm{Mo}$, are distinguished by an increased content of alkaloids. This fact indicates the influence of heavy metals on the antioxidant defense system and the participation of alkaloids in the adaptation of plants growing under conditions of metal stress $[16,17]$.

\section{Conclusion}

The main sites of localization of the alkaloids P. mollis, S. caucasicum, S. asperum, and E. vulgare are rhizomes with roots, glandular trichomes of leaves and stems, epidermal cells adjacent to the base of individual multicellular covering hairs. P. mollis, S. caucasicum, $S$. asperum, and E. vulgare are relatively weak accumulators of alkaloids $(<1 \%)$. The content of alkaloids in the aboveground phytomass decreases in the series $S$. asperum $>S$. caucasicum $>$ E. vulgare, and in the underground - S. caucasicum $>S$. asperum $>$ E. vulgare $>P$. mollis. The accumulation level of alkaloids in the rhizomes and roots of $S$. caucasicum and $S$. asperum exceeds that in the shoots; at the end of the growing season, there is an increase in the total content of alkaloids in the roots (by 21.0-29.2\%) and a decrease in the stems with leaves (by 7.2-12.8\%). In plants of E. vulgare, the content of alkaloids is higher in the aerial part; in the Seed Formation Stage, the accumulation of alkaloids in the stems with leaves decreases by $11.6 \%$, and in the roots increases by $20.0 \%$. The content of alkaloids in the aboveground phytomass of $S$. asperum, E. vulgare is characterized by moderate, and $S$. caucasicum - noticeable variability. In the underground phytomass of the studied species, the level of accumulation of alkaloids varies slightly. The relationship between climatic factors and the accumulation of alkaloids in the shoots is higher than in the roots. Altitude above sea level has no significant effect on the accumulation of alkaloids in the phytomass of the studied species. The accumulation of alkaloids in roots and shoots correlates with the metal content in the underground and aboveground phytomass. The strength of the relationship between the accumulation of alkaloids and the content of trace elements in the phytomass varies from high $(\mathrm{Cu}, \mathrm{Zn}, \mathrm{Mo})$ to medium $(\mathrm{Mn}, \mathrm{Pb})$. The results obtained indicate the need to take into account environmental factors in the implementation of medicinal collections and the preparation of green mass for the production of silage. The revealed patterns can be recommended for detecting cenopopulations of S. caucasicum, S. asperum, E. vulgare, and $P$. mollis with the maximum accumulation of pyrrolizidine alkaloids and predicting their content in specific areas.

\section{References}

1. J. Gershenzon, Plant Physiology, 347 (2003)

2. V.B. Roshchina, V.V. Roshchina, The Excretory Function of Higher Plants, 476 (2012)

3. T. Aniszewski, Alkaloids - secret of life: alkaloids chemistry, biological significance, applications and ecological role, 335 (2007)

4. A.M. Babykina T.P. Antsupova, Bulletin of the Buryat State University, 4, 85 (2012)

5. A.A. Terekhin, V.V. Vandyshev, Technology of cultivation of medicinal plants, 201 (2008)

6. V. Rai, S. Khatoon, S.S. Bisht, S. Mehrotra, Chemosphere, 61, 16442005)

7. G.N. Buzuk, M.Ya. Lovkova, AgroXXI, 7-9, 43 (2011)

8. A. El-Shazly, M. Wink, Diversity, 6, 188 (2014)

9. S.O. Onduso, M.M. Ng'ang'a, W. Wanjohi, A. Hassanali, Chemosphere, 15(2), 65 (2017). 
10. G.A. Cordell, The Alkaloids - Chemistry and Biology, 69, 609 (2011)

11. F. Stickel, H.K. Seitz, Public Health Nutrition, 3, 501 (2000

12. C.E. Couet, C. Crews, A.B. Hanley, Natural Toxins, 4, 163 (1996)

13. D. Frohne, H.J. Pfänder, Poisonous plants: a handbook for doctors, pharmacists, toxicologists and veterinarians, 469 (2005)

14. T. Mclellan, American Journal of Botany, 92,1616 (2005)

15. G.K. Kuznetsova, Genetic resources of medicinal and aromatic plants, 320 (2001).

16. R.A. Hassanein., H.A. Hashem, M.H. El-deep, A. Shouman, Journal of Stress Physiology \& Biochemistry, 9(4), 145 (2013)

17. W. Roos, S. Evers, M. Hieke, M. Tschope, B. Schumann Plant Physiology, 118, 349 (1998) 